\section{HOIME CLASS: EDUCATIONAL ALTERNATIVE IN TIMES OF PANDEIMIC FOR STUDENTS ENROLLED IN BASIC EDUCATION IN THE STATE OF AMAZONAS, BRAZIL}

KEY WORDS: remote learning, digital technologies, home tuition, hybrid learning, online education

\title{
Melise IMaia
} Ribeiro*

FAVENI Faculty. Graduate Program in Education. street, Angelo Altoé, n 888, Santa Cruz -Venda Nova do Imigrante - ES, Brazil. *Corresponding Author

The objective of this research is to know new decisions about the teaching and learning process in the context of the pandemic in the state of Amazonas, Brazil. The pandemic suspended classroom classes at more than 200 schools, causing the reorganization of pedagogical practices in distance education. The result was the applicability of the Special Regime of Non-Attendance Classes adopted by the Government of Amazonas (Aula em Casa Project). It is concluded that new directions can be taken from formal education in view of this new reality.

\section{INTRODUCTION}

The emerging challenges of education and the speed of change resulted in adaptability. The challenges gained enormous proportions with the COVID-19 pandemic. (ONYEMA,2020).

Distance Education (EaD) in Brazil was already foreseen as a teaching modality in the Law of Guidelines and Bases (LDB), No. 9,394/96 since its enactment. With the Covid-19 pandemic crisis, in the year 2020, this nomenclature started to be constantly used in the emerging context. (DE OLIVEIRA, 2021; SANTANA, 2020).

From this new context, new habits and the Government of the State of Amazonas emerged. In order to guarantee the students' classes, the project for the Special Regime of NonAttendance Classes was created. (DA SILVA, 2021).

According to Castaman (2021), pedagogical guidelines, diversified strategies, reorganization of plans, new contents, new technologies and the teacher's actions were rethought.

This paper aims to analyze the pedagogical practices adopted by the Government of Amazonas, the Home Class Project, in the pandemic context, using Document Analysis and Bibliographic Research as a methodological alternative.

The information analyzed here was based on the official websites of the State Secretariat for Education and Teaching Quality of Amazonas (SEDUC-AM).

\section{PROJECT HOME CLASS}

The special regime of non-presential classes - Home Class Project, was implemented by the Government of Amazonas, through Resolution 30/2020 - CEE/AM, based on Decrees Nos. 42,061, 42,063 and 42,087 of 16, 17 and 19/03, respectively. In this document, strategies and guidelines for the initial confrontation of suspension from school activities were indicated.

According to Gomes and Thomé (2020), the pedagogical guidelines restructured the content grid, provided guidelines for school managers, new practices for teachers, parents and students.

They sought to ensure essential learning, made the year full of challenges, to remain connected to the hope that a time of difficulties is being lived. (SILVA, 2021).

The Department of Education was concerned with offering various resources so that students could have access to classes. Teachers from the State and Municipal Education Network were selected to teach the classes that were recorded at the Department of Education's Media Center.

According to Alves and Coelho (2021), in addition to the |www.worldwidejournals.com capital, the classes were also broadcast throughout the interior of the State of Amazonas. In an organized way, the classes followed a schedule with schedules established by teaching modality and grade.

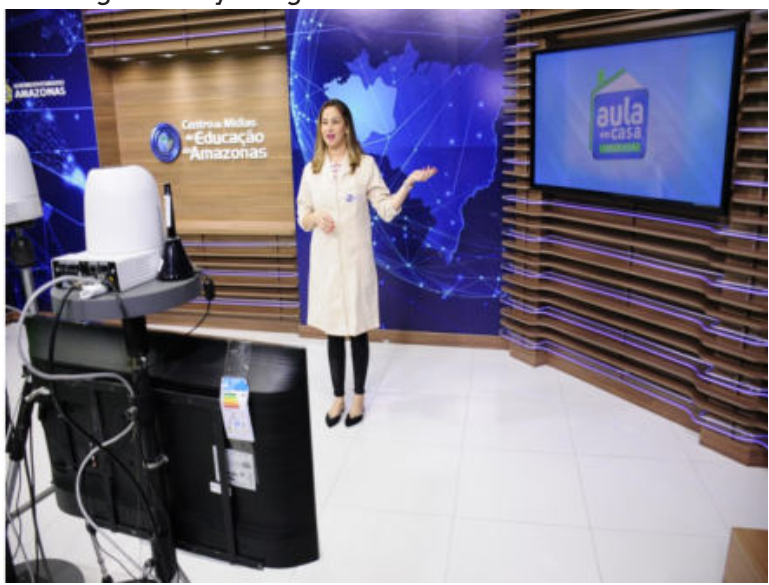

Figure 1: Home Class Project / Cleudilon Passarinho Sources: http://www.educacao.am.gov.br/aula-emcasa/

According to, De Azedo Souza (2021), in addition to this initiative, the Department of Education also created two platforms called Virtual Learning Environment - AVA and Saber + , which published the weekly schedule of classes, support notebooks and other subsidies to support students, teachers and school managers. Thus, the State of Amazonas was a pioneer in the organization of remote classes.

\section{THE NEW REALITY OF FAMILIES, PARENTS AND STUDENTS}

The Law of Guidelines and Bases of National Education (Brasil, 1996), declares that education is the duty of the family and the state. The Pedagogical Guidelines for the Home Class include relevant guidelines for parents and suggest that: the family should support children's learning; guide them to take notes; encourage the deepening of knowledge transmitted and monitor the routine of communication between teachers and students. So, in a collaborative way, guarantee educational success in such difficult times.

It is up to the students to watch the classes assiduously broadcast, organize the time to carry out the requested activities, write down doubts for further clarification, access educational websites and discover themselves as the protagonists of their learning. For the success of this project, the importance of engagement and proactivity of everyone involved is highlighted.

\section{CONCLUSIONS}

This article presented the Home Class Project, developed by 
the Government of Amazonas in basic education units in the capital. The state came out ahead of the others, presenting solutions for the continuation of pedagogical activities due to the work developed at the Media Center.

The state, in its functions, assumed responsibilities aimed at guaranteeing essential student learning. Faced with enormous difficulties, there is a clear commitment to fulfilling the pedagogical commitment assumed with the Amazonian population, using ICTs as urgent measures to overcome the situation.

The immediacy of the pandemic called for, even if hastily, pedagogical measures that impacted the school life of thousands of students. Such impacts will have consequences for a long time during the return to normality of activities.

Covid-19 showed that the practices present in school spaces present some weaknesses in the educational system in general. And that the public power must be the tireless guarantor of rights, in all areas, for the population.

The pandemic context signals the importance of modernizing education, not only re-equipping, but constant training of personnel, so that the era of technological society becomes a reality for all.

And it is essential to look and walk towards the future, aiming at transforming the challenges of a historic and difficult year into fuel for this transformation process.

\section{REFERENCES:}

[1] ONYEMA, Edeh Michael et al. Impacto da pandemia de Coronavirus na educação. Jornal de Educação e Prática, v. 1 1,n. 13, pág. 108-121, 2020.

[2] DE OLIVEIRA, Marciel Costa. A Importância da Educação à Distância no Contexto da Pandemia de COVID 19. RACE-Revista de Administração do Cesmac,v. 10, p. 73-84,2021

[3] SANTANA, Camila Lima et al. AULA EM CASA: EDUCAÇÃO, TECNOLOGIAS DIGITAIS E PANDEMIA COVID-19. Interfaces Científicas-Educação, v. 10, n. 1,p. 75-92,2020.

[4] DA SILVA, Iolete Ribeiro; DA SILVA, Camila Ribeiro. O projeto 'Aulas em Casa'e a educação remota durante a pandemia do COVID-19: análise da experiência do estado do Amazonas. Revista Educar Mais ,v. 5, n. 1, pág. 2534,2021 .

[5] Castaman, AS, \& Rodrigues, RA (2020). Educação a Distância na crise COVID19: um relato de experiência. Research, Society and Development , 9 (6), el80963699-el80963699.

[6] Gomes, J. C., \& Thomé, Z R. C. (2020). Educação a Distância em Tempos de Pandemia: Entre os Híbridos e Agenciamentos de uma Experiência. EaD em Foco, 10(3).

[7] SILVA, D. N. Educação no Amazonas em Tempos de Pandemia: Experiências, Tendências e Desafios. Recife:Even3 Publicações, 2021

[8] Alves, J. D. L. V., \& Coelho, L. R. (2021). Formação e Prática Docente: compreendendo as lógicas que orientam a ação pedagógica na Educação infantil em Manaus/AM/Teacher Training and Practice: understanding the thoughts that guide pedagogical action in early childhood education in Manaus/AM. Brazilian Journal of Development, 7(2), 15112-15125.

[9] de Azedo Souza, A. L., de Azevedo Vilaça, A. L., \& Teixeira, H. B. (2021). A METODOLOGIA ATIVA E SEUS BENEFÍCIOS NO PROCESSO DE ENSINO APRENDIZAGEM: doi. org/10.29327/217514.7. 1-23. Revista Ibero-Americana de Humanidades, Ciências e Educação, 7(1), 17-17. 